\title{
DAMPAK SOSIO-EKONOMIS DAN SOSIO-EKOLOGIS KONVERSI LAHAN
}

\author{
The Socio-Economic and Socio-Ecological Impact of Land Conversion
}

\author{
Astri Lestari ${ }^{*}$ dan Arya Hadi Dharmawan \\ Departemen Sains Komunikasi dan Pengembangan Masyarakat, Fakultas Ekologi Manusia, IPB \\ *)Email : astrilestari@yahoo.com
}

Diterima 16 Februari 2011/Disetujui 30 Maret 2011

\begin{abstract}
Conversion of agricultural land is one of the phenomena of change the agricultural land designated into non agricultural designated. The purposes of this study are 1) to know the types of land conversion at Desa Tugu Utara, 2) to know the social-economic impact of land conversion at Desa Tugu Utara, and 3) to know the social-ecological impact of land conversion at Desa Tugu Utara. This study uses a quantitative approach supported by the use of qualitative approach. The result of the study showed that the type of land conversion in the village (2000-2010) consists of three types of land conversion: 1) land conversion type by location (open/closed), 2) land conversion type by the speed of change of land utilization (fast/slow), and 3) land conversion type by the actors involved in the land conversion (local residents/non-local resident). In general, land conversion gives a negative impact on social-economics conditions of household in the region, either in the agricultural sector or in the non-agricultural sector and also brings a negative impact on socialecological system because it causes many environmental degradation.
\end{abstract}

Keywords: agricultural land, types of land conversion, environmental degradation

\section{PENDAHULUAN}

Desa Tugu Utara, Kecamatan Cisarua, Bogor merupakan salah satu desa yang mengalami konversi lahan pertanian. Desa ini berada di bagian hulu Daerah Aliran Sungai (DAS) Ciliwung dan merupakan kawasan wisata yang banyak dikunjungi wisatawan baik dalam negeri maupun luar negeri, sehingga daerah ini dijadikan sebagai tempat peristirahatan yang tepat dikala perkotaan tidak lagi memberikan keindahan panorama alam dan kenyamanan bagi penduduknya. Hal ini mendorong berbagai pihak melakukan perubahan peruntukkan lahan pertanian ke peruntukkan lahan non pertanian seperti bangunan-bangunan fasilitas wisata berupa villa dan restoran.

Perubahan fungsi lahan di kawasan hulu dapat menimbulkan berbagai dampak yang tidak hanya berakibat pada kawasan sekitar konversi, melainkan juga berakibat pada kawasan yang ada di bagian hilir DAS Ciliwung. Hal ini terjadi karena adanya interkoneksitas kawasan hulu dan hilir. Salah satu bencana yang sering menjadi sorotan adalah bencana banjir di hilir DAS Ciliwung tepatnya di Jakarta yang terjadi akibat perubahan tata ruang di bagian hulu yaitu wilayah Bopunjur (Bogor, Puncak, Cianjur). Jika terjadi banjir di kawasan hilir, kebanyakan orang menyebutnya sebagai "Banjir kiriman dari Bogor". Istilah ini menandakan bahwa fungsi wilayah hulu sebagai wilayah resapan air tidak lagi berjalan dengan baik

Berdasarkan latar belakang yang dikemukakan di atas, penulisan ini menitikberatkan pada kajian mengenai dampak konversi lahan pertanian menjadi lahan non pertanian pada kehidupan sosial ekonomi rumah tangga dan sosial ekologi kawasan yang mengalami konversi lahan. Telaah yang dilakukan dalam penulisan ini juga hendak mengetahui tipe konversi lahan yang terjadi di Desa Tugu Utara

\section{Pertanyaan Penelitian}

Penelitian ini dilakukan dengan merangkum tiga pertanyaan yakni: 1) Apa saja tipe-tipe konversi lahan di lokasi penelitian?, 2) Bagaimana dampak sosio- ekonomis konversi lahan terhadap masyarakat lokal?, 3) Bagaimana dampak sosio-ekologis konversi lahan terhadap masyarakat lokal?

\section{Tujuan Penelitian}

Penelitian ini bertujuan untuk 1) mengetahui tipe-tipe konversi lahan di lokasi penelitian; 2) mengetahui dampak sosio-ekonomis konversi lahan terhadap rumah tangga setempat; dan 3) mengetahui dampak sosioekologis konversi lahan terhadap kawasan setempat. 


\section{PENDEKATAN TEORITIS}

\section{Konsep dan Struktur Agraria}

Konsep agraria merujuk pada berbagai hubungan antara manusia dengan sumber-sumber agraria serta hubungan antar manusia dalam rangka penguasaan dan pemanfaatan sumber-sumber agraria (Sitorus, 2002). Selanjutnya Sitorus (2002) juga menyatakan dalam pemanfaatan sumber-sumber agraria terdapat tiga subjek agraria yang dibedakan menjadi tiga yaitu komunitas, pemerintah dan swasta. Oleh karena itu, struktur agraria pada dasarnya menjelaskan bagaimana struktur akses pihak-pihak yang terkait dengan sumberdaya agraria. Dengan kata lain, hubungan-hubungan sosio-agraria dapat menjelaskan bagaimana struktur agraria suatu masyarakat.

\section{Definisi dan Tipe Konversi Lahan}

Iqbal dan Soemaryanto (2007) menyatakan bahwa istilah alih fungsi (konversi) lahan merupakan perubahan spesifik dari penggunaan untuk pertanian ke pemanfaatan bagi non pertanian. Konversi lahan adalah berubahnya satu penggunaan lahan ke penggunaan lainnya, sehingga permasalahan yang timbul akibat konversi lahan banyak terkait dengan kebijakan tataguna tanah (Ruswandi, 2005). Kegiatan konversi lahan memiliki beragam pola tertentu tergantung pada kebutuhan dari usaha konversi lahan Soemaryanto, et.al. (2001) memaparkan bahwa pola konversi lahan dapat ditinjau dari beberapa aspek. Pertama, menurut pelaku konversi, yang dibedakan menjadi dua yaitu: 1) Alih fungsi secara langsung oleh pemilik lahan yang bersangkutan dan

2) Alih fungsi yang diawali dengan alih penguasaan. Pola konversi lahan yang ditinjau menurut prosesnya terbagi menjadi dua yaitu gradual dan seketika. Berdasarkan faktor pokok konversi, pelaku, pemanfaat dan prosesnya, Sihaloho (2004) membedakan konversi lahan menjadi tujuh pola atau tipologi. Ketujuh pola tersebut antara lain: 1) Konversi Gradual-Berpola Sporadis; 2) Konversi Sistematik berpola "enclave”; 3) Konversi Lahan sebagai Respon Atas Pertumbuhan Penduduk (population growth driven land conversion); 4) Konversi yang disebabkan oleh Masalah Sosial (social problem driven land conversion); 5) Konversi "Tanpa Beban"; 6) Konversi Adaptasi Agraris; dan 7) Konversi Multi Bentuk atau Tanpa Bentuk/Pola.

\section{Dampak Sosio-Ekonomis}

Konversi lahan pertanian memberikan dampak positif pada sektor non pertanian, seperti tersedianya sarana prasarana, berlangsungnya pembangunan, dan pendapatan yang diperoleh lebih besar dibandingkan sektor pertanian. Hal ini menyebabkan para petani beralih profesi ke sektor non pertanian agar standar hidup terpenuhi (Utama, 2006). Ditambah lagi dengan terjadinya penurunan produksi pertanian, maka petani pun semakin menjauh dari sektor pertanian. Saefulhakim dan Nasution (1995) sebagaimana dikutip oleh Akib (2002) menyatakan bahwa hal penting yang harus diperhatikan adalah bahwa pada kenyataannya masyarakat lokal (pemilik tanah semula dan buruh tani) banyak sekali yang tak dapat menikmati kesempatan kerja dan pendapatan dari aktivitas ekonomi yang baru. Pemetik manfaat umumnya justru pendatang. Hal ini disebabkan adanya senjang permintaan dan penawaran tenaga kerja maupun karena kalah bersaing dengan pendatang.

\section{Dampak Sosio-Ekologis}

Istilah ekologi berasal dari bahasa Yunani, oekos berarti rumah dan logi atau logos berarti ilmu. Sehingga secara harfiah ekologi dapat diartikan sebagai ilmu tentang makhluk hidup dalam rumahnya atau dapat diartikan juga sebagai ilmu tentang rumah tangga makhluk hidup (Adiwibowo, 2007). Ekologi mempelajari bagaimana makhluk hidup berinteraksi timbal balik dengan lingkungan hidupnya baik yang bersifat hidup (biotik) maupun yang bersifat tak hidup (abiotik) (Adiwibowo, 2007).

Dilihat dari sudut pandang ekologi, adanya konversi lahan dapat berdampak pada terganggunya ketahanan daya dukung lingkungan dimana jika dilakukan secara terus menerus tanpa adanya pengendalian, dapat menyebabkan terjadinya fenomena degradasi lingkungan, seperti longsor, erosi, penurunan penutupan lahan (vegetasi), dan sedimentasi. Hal ini dapat dilihat dari berbagai bencana alam yang terjadi di Indonesia belakangan ini. Sebagai contoh terjadinya banjir di daerah Bogor-Jakarta pada bulan Februari 2010 merupakan bencana alam yang menurut Satria $(2010)^{1}$ merupakan bencana alam akibat faktor alam dan faktor manusia (antropogenetik). Tingginya curah hujan merupakan bencana alam akibat faktor alam, sedangkan rendahnya resapan air ke tanah akibat perubahan alih fungsi lahan dan bangunan di sekitar kawasan Puncak, sehingga bencana ini termasuk bencana alam akibat faktor antropogenetik. Hal ini mengindikasikan bahwa konversi lahan termasuk pada penyebab bencana alam akibat faktor kedua yang juga dapat dikatakan sebagai "bencana buatan,"2.

\section{Kerangka Pemikiran}

Konversi lahan pertanian ke lahan non pertanian seperti industri, pemukiman, villa dan lain sebagainya diduga disebabkan oleh beberapa faktor yang dibagi menjadi faktor eksternal dan faktor internal, selain itu kegiatan konversi lahan juga memiliki pola atau tipologi yang berbeda-beda sesuai dengan kondisi dan situasi. Berdasarkan hasil wawancara dengan infoman dan merujuk pada hasil penelitian yang dilakukan oleh Soemaryanto (2001) dan Sihaloho (2004), peneliti membuat tipe konversi lahan pertanian yang terjadi di Desa Tugu Utara berdasarkan tiga sudut pandang yaitu konversi lahan berdasarkan letak kawasan yang terdiri tipe terbuka dan tertutup, berdasarkan tingkat kecepatan konversi yang terdiri dari tipe konversi cepat dan lambat, dan konversi lahan berdasarkan pihak pelaku konversi yang terdiri dari warga lokal dan warga luar desa. Oleh karena itu, konversi lahan memiliki dampak pada aspek sosial ekologi dan sosial ekonomi masyarakat setempat.

\footnotetext{
${ }^{1}$ Arif Satria. 2010. Ekologi-Politik Banjir. Bogor : Kompas

${ }^{2}$ Bencana buatan merupakan bencana alam yang terjadi akibat tingkah laku manusia yang tidak selaras dengan alam
} 
Adanya perubahan pada ekologi sekitar kawasan konversi seperti perubahan kondisi lingkungan dimana terjadi kerusakan lingkungan, dapat berdampak pada kondisi ekonomi dan mengakibatkan terjadinya perubahan sosial bagi masyarakat setempat. Kerangka berpikir dalam penelitian ini diilustrasikan pada Gambar 1 .

Gambar 1. Kerangka Berpikir

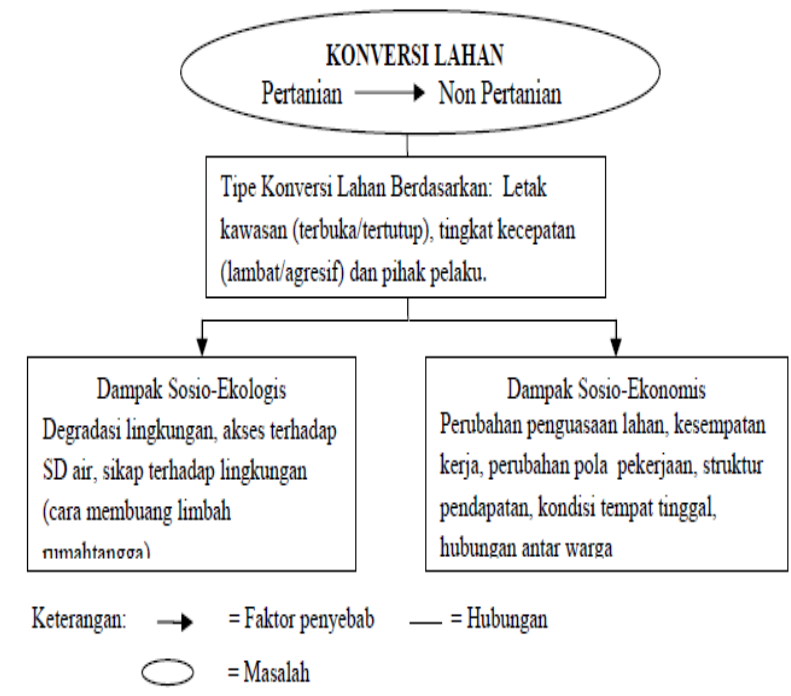

\section{PENDEKATAN LAPANGAN}

\section{Metode Penelitian}

Penelitian ini menggunakan pendekatan kuantitatif yang didukung oleh pendekatan kualitatif. Pendekatan kuantitatif digunakan untuk mengetahui kondisi sosial ekonomi setiap rumah tangga yang menjadi sampel penelitian, sedangkan pendekatan kualitatif digunakan untuk melihat proses konversi yang terungkap dari hasil penelitian kuantitatif. Pendekatan kualitatif dilakukan melalui studi kasus, observasi dan wawancara mendalam.

\section{Data dan Sumber Data}

Penelitian dilakukan di Desa Tugu Utara, Kecamatan Cisarua, Kabupaten Bogor, sejak bulan Oktober sampai November 2010. Data sekunder diperoleh melalui studi literatur yang sumbernya berasal dari berbagai dokumendokumen pemerintah Desa Tugu Utara, data-data dari dinas-dinas terkait, makalah ilmiah dan lain sebagainya, sedangkan data primer yang dikumpulkan melalui penyebaran kuesioner kepada 60 responden dari dua RT (Rukun Tetangga) berbeda. Pemilihan RT ditentukan melalui teknik cluster sampling (Singarimbun, 1989). Seluruh kampung penelitian dibagi menjadi dua kluster yaitu kampung yang jauh dari jalan raya sebanyak 12 kampung dan kampung yang dekat dengan jalan raya sebanyak 8 kampung. Dipilih dua kampung secara purposif berdasarkan informasi dari aparat setempat yaitu Kampung Sampay mewakili kampung yang dekat jalan raya dan Kampung Sukatani mewakili kampung yang jauh dari jalan raya. Dari dua kampung tersebut dipilih dua RT untuk menjadi sampel kedua yang ditentukan secara purposif. RT yang terpilih yaitu RT 01/RW 03 sebanyak 121 rumah tangga dan RT 06/RW 04 sebanyak 91 rumah tangga. Dari kedua RT dipilih masing-masing
30 responden, sehingga total responden secara keseluruhan sebanyak 60 responden.

\section{Teknik Analisa Data}

Data primer diolah dan disajikan dalam bentuk tabel frekuensi serta tabel silang untuk melihat keterkaitan dari aspek-aspek yang menjadi dampak sosial ekonomi dan sosial ekologi konversi lahan masyarakat Desa Tugu Utara. Data primer tersebut selanjutnya dianalisis sesuai dengan tujuan penelitian. Sementara itu untuk pendekatan kualitatif digunakan metode triangulasi untuk memberikan penguatan dari data yang diperoleh melalui kuesioner dengan melibatkan wawancara mendalam dan observasi. Gabungan data tersebut diolah dan dianalisis dengan disajikan dalam bentuk teks naratif, matriks, atau bagan, kemudian ditarik kesimpulan dari semua data yang telah diolah.

\section{HASIL DAN PEMBAHASAN}

\section{Tipe-Tipe Konversi Lahan}

Tipe-tipe konversi lahan ditentukan berdasarkan hasil pengamatan dan wawancara dengan informan yang ada di Desa Tugu Utara serta merujuk pada hasil penelitian yang dilakukan oleh Soemaryanto (2001) dan Sihaloho (2004). Dari hasil observasi dan wawancara tersebut maka diperoleh tiga sudut pandang (dimensi) konversi lahan yang terjadi di kawasan ini, yaitu:

\section{Dimensi letak kawasan}

Kampung Sampay kegiatan konversi lahan secara besarbesaran untuk membangun rumah, villa dan hotel sudah menjadi suatu fenomena yang biasa karena kampung ini telah mengalami konversi lahan yang lebih terbuka dibandingkan dengan Kampung Sukatani. Di kampung ini terdapat sarana dan prasarana umum seperti rumah makan dan restoran sebanyak tujuh buah, villa sebanyak 36 buah, 17 warung dan toko, dua mini market, satu depot isi ulang air mineral, tiga jasa tiket penerbangan/money changer dan dua salon kecantikan, sementara untuk lahan pertanian di kampung ini semakin lama semakin berkurang dan mengakibatkan konversi lahan yang terjadi di Kampung Sampay akhir-akhir ini tidak sebesar konversi di Kampung Sukatani karena sudah tidak ada lagi lahan yang dapat dikonversi ${ }^{3}$. Dari data kuantitatif diperoleh sejumlah responden yang melakukan konversi lahan pertanian ke peruntukkan lahan non pertanian seperti rumah, vila dan hotel sebanyak lima rumah tangga.

Berbeda dengan Kampung Sukatani yang hanya mengalami perubahan peruntukkan lahan berupa bangunan villa dan green house yang tidak terlalu mencolok sehingga kampung ini masih penuh dengna lahan pertanian. Kegiatan konversi lahan di kampung ini jauh lebih tertutup karena letaknya yang jauh dari jalan raya dan sulitnya alat-alat transportasi untuk menjangkau tempat-tempat yang berada di bagian atas kampung karena jalannya sempit, menanjak dan penuh dengan

\footnotetext{
${ }^{3}$ Konversi lahan yang sedikit di Kampung Sampay menunjukkan tidak ada lagi lahan yang dapat dikonversi karena sebagian besar lahan telah berubah menjadi bangunan -bangunan
} 
bebatuan. Di kampung ini kegiatan konversi lahan menjadi lebih besar dibandingkan Kampung Sampay karena masih banyaknya lahan pertanian yang dapat dialihfungsikan menjadi peruntukkan diluar pertanian. Dari 30 responden sebanyak sembilan rumah tangga melakukan konversi lahan pertanian menjadi penggunaan diluar pertanian.

Uraian di atas menunjukkan terjadinya pergeseran kegiatan konversi lahan dari kawasan yang dekat jalan raya (konversi tinggi) ke kawasan yang jauh dari jalan raya (konversi rendah) sehingga di masa yang akan datang keadaan Kampung Sukatani yang kaya akan lahan pertanian dapat menjadi seperti kondisi Kampung Sampay saat ini yang penuh dengan bangunan-bangunan. Secara ekologis kondisi Kampung Sampay yang sebagian besar lahannya telah beralih menjadi bangunan menunjukkan bahwa kampung ini sudah mengalami krisis lingkungan dimana alam memberikan manfaat kepada manusia sedangkan manusia sendirimemberikan kerugian pada alam (Dharmawan, 2007).

\section{Dimensi Tingkat Kecepatan}

Tipe konversi ini merupakan sehamparan lahan yang terkonversi dengan melihat tingkat kecepatan terjadinya perubahan peruntukkan lahan di kawasan tersebut. Secara umum fenomena konversi lahan di Desa Tugu Utara melaju dengan cepat pada kisaran tahun 1995-2002 dan mulai melaju lambat dimulai tahun 2002.Terjadi perbedaan kecepatan laju konversi lahan tersebut karena sudah adadampak yang dirasakan akibat konversi lahan terutama setelah sering terjadinya banjir, sehingga lahan pertanian yang sudah dialihfungsikan ke bentuk diluar pertanian secara perlahan mulai dialihfungsikan lagi ke pemanfaatan semula karena pihak pemerintah sedang melakukan upaya pembenahan kawasan Puncak agar tetap dapat menjalankan fungsinya sebagai kawasan resapan air di wilayah Bopunjur (Bogor Puncak Cianjur).

Pada tahun 1995-2002 konversi lahan di Kampung Sampay lebih cepat dibandingkan dengan konversi lahan di Kampung Sukatani karena mudahnya akses pada jalan raya dan sarana perekonomian. Hal ini menyebabkan semakin sedikit lahan pertanian yang ada di Kampung Sampay, sementara kegiatan perubahan peruntukkan lahan di Kampung Sukatani berlangsung secara lambat karena saat ini masih banyak lahan pertanian yang dapat dimanfaatkan rumah tangga setempat. Seperti pada uraian sebelumnya yang menjelaskan tentang adanya pergeseran kegiatan konversi lahan ke daerah-daerah yang masih banyak lahannya dapat membuat Kampung Sukatani menjadi target dari kegiatan konversi lahan selanjutnya.

\section{Dimensi Pihak Pelaku Konversi}

Kebutuhan akan tempat tinggal dan keterdesakan ekonomi bagi warga lokal serta keinginan untuk melakukan investasi bagi warga luar desa (para pemilik modal/investor) menjadi salah satu faktor yang mendorong terjadinya konversi lahan.

\section{Warga lokal}

Kepadatan penduduk di Desa Tugu Utara semakin meningkat setiap tahunnya karena bertambahnya jumlah warga lokal atau pun karena jumlah migrasi warga yang semakin besar sehingga banyak warga yang melakukan konversi lahan di lahan produktif untuk dijadikan tempat tinggal. Berdasarkan hasil penelitian kepada 60 responden rumah tangga Kampung Sampay dan Kampung Sukatani terdapat enam rumah tangga (10 persen) yang mengubah lahan pertanian menjadi tempat tinggal. Salah satu kasus perubahan peruntukkan lahan pertanian menjadi tempat tinggal yaitu kasus yang terjadi pada keluarga Bapak Haji Jpr. Saat itu beliau sudah menikah dan belum memiliki tempat tinggal sehingga berinisiatif untuk mengkonversi lahan pertanian miliknya karena tidak memiliki cukup uang untuk membeli rumah ditempat lain. Tidak ada penyesalan dari bapak Haji Jpr setelah lahannya terkonversi karena menurut beliau jika lahannya tidak dikonversi menjadi tempat tinggal, mungkin saat ini beliau dan keluarga tidur dijalanan. Uraian di atas menunjukkan bahwa kebutuhan akan tempat tinggal menjadi salah satu pendorong terjadinya konversi lahan pertanian.

Sebagian besar rumah tangga Desa Tugu Utara sudah tidak lagi memiliki lahan milik sendiri baik lahan yang produktif maupun lahan yang kurang produktif. Hal ini terjadi karena kondisi ekonomi rumah tangga mengalami penurunan apalagi setelah terjadinya krisis ekonomi tahun 1998. Krisis ekonomi tersebut mengakibatkan lahan menjadi suatu komoditas yang layak untuk diperjualbelikan agar dapat memenuhi kebutuhan hidup. Sebanyak 26,08 persen rumah tangga menjual lahan pertanian miliknya sendiri dimana 17,4 persen rumah tangga Kampung Sampay dan 8,7 persen rumah tangga Kampung Sukatani ${ }^{4}$. Kondisi ini mengakibatkan terjadinya perubahan struktur agraria terkait penguasaan lahan pertanian. Selain itu, ada pula rumah tangga yang keluar dari kampung atau desanya sendiri untuk memperoleh keuntungan ekonomi diluar pertanian, sehingga pola kerjanya pun berubah dari bekerja di sektor pertanian menjadi bekerja di sektor non pertanian.

\section{Warga Luar Desa (Pemilik Modal/Investor)}

Kawasan Desa Tugu Utara merupakan kawasan pinggiran kota yang sering dijadikan tempat peristirahatan bagi para pengunjung yang berasal dari luar kota serta banyak pemilik modal yang melakukan investasi lahan. Berdasarkan hasil penelitian kepada 23 responden yang bergerak dibidang pertanian, terdapat rumah tangga yang melakukan konversi lahan pertanian menjadi peruntukkan lahan non pertanian seperti hotel sebesar 4 persen, villa sebesar 17 persen dan mesjid sebesar 4 persen. Kasus terbaru yang terjadi di desa ini yaitu alih fungsi lahan untuk

\footnotetext{
${ }^{4}$ Jumlah responden diambil dari rumah tangga yang berkecimpung di dunia pertanian yaitu sebanyak 23 rumah tangga atau 23,33 persen dari 60 rumah tangga
} 
digunakan sebagai kegiatan perekonomian berupa pembangunan sebuah hotel dan restoran besar di atas tanah produktif yang baru dipromosikan sekitar bulan Oktober tahun 2010. Bangunan tersebut sangat luas dan memiliki nilai estetika tersendiri bagi pengunjungnya, karena letak bangunan dipinggir jalan dan berada di ketinggian sehingga mampu menyuguhkan pemandangan yang indah.

Para pemilik modal yang memanfaatkan lahan di Desa Tugu Utara cenderung kurang memberikan kesempatan kepada warga lokal untuk bekerja ditempat usahanya. Para pemilik modal ini biasanya menggunakan jasa profesional dengan kualifikasi tertentu yang sebagian besar tidak dimiliki warga lokal, sehingga hal ini merugikan warga setempat.

\section{Dampak Sosio-Ekonomis Konversi Lahan Pertanian}

Fenomena konversi lahan pertanian memberikan perubahan pada kehidupan sosial ekonomi rumah tangga Desa Tugu Utara. Adapun dampak dari kegiatan konversi lahan tersebut antara lain perubahan struktur agraria, perubahan kesempatan kerja baik di sektor pertanian maupun diluar sektor pertanian, perubahan pola kerja, struktur pendapatan yang diperoleh, kondisi tempat tinggal dan hubungan antar warga. Terdapat perbedaan dampak yang diterima oleh rumah tangga di kawasan yang dekat dengan jalan raya dan rumah tangga di kawasan yang jauh dari jalan raya.

\section{Struktur Agraria}

\section{a. Perubahan Penguasaan Lahan}

Konversi lahan merupakan akibat dari perpindahan penguasaan lahan yang pada akhirnya menyebabkan terjadinya perubahan penguasaan lahan rumah tangga setempat. Pada penelitian ini penguasaan lahan pertanian dikategorikan menjadi lima yaitu kategori tidak punya lahan, tumpang sari, bagi hasil, sewa dan milik. Selama sepuluh tahun terakhir (20002010) telah terjadi perpindahan penguasaan lahan di Desa Tugu Utara yang berimplikasi pada terjadinya perubahan derajat penguasaan lahan rumah tangga setempat. Data pada Tabel 1 menunjukkan perpindahan penguasaan lahan rumah tangga Kampung Sampay dan Kampung Sukatani selama kurun waktu sepuluh tahun.

Tabel 1. Perubahan Derajat Penguasaan Lahan Rumah Tangga Kampung Sampay dan Kampung Sukatani Periode 10 Tahun (2000-2010)

\begin{tabular}{|l|l|l|}
\hline $\begin{array}{l}\text { Derajat kuatnya } \\
\text { penguasaan lahan }\end{array}$ & \multicolumn{1}{|c|}{$\begin{array}{l}\text { Kampung } \\
\text { Sampay }\end{array}$} & \multicolumn{1}{|c|}{$\begin{array}{l}\text { Kampung } \\
\text { Sukatani }\end{array}$} \\
\hline Tunakisma & $\begin{array}{l}\text { Meningkat sebanyak } \\
4 \mathrm{rt} \text { (dari } \\
22 \mathrm{rt} \text { menjadi 26 rt) }\end{array}$ & $\begin{array}{l}\text { Meningkat } \\
\text { sebanyak 1 rt } \\
\text { (dari 15 rt menjadi } \\
16 \mathrm{rt})\end{array}$ \\
\hline
\end{tabular}

\begin{tabular}{|l|l|l|}
\hline Tumpang Sari & $\begin{array}{l}\text { Tidak berubah, tetap } \\
\text { tidak ada }\end{array}$ & $\begin{array}{l}\text { Tidak berubah, } \\
\text { tetap 5 rt }\end{array}$ \\
\hline Bagi Hasil & $\begin{array}{l}\text { Menurun (dari 2 rt } \\
\text { menjadi } \\
\text { tidak ada) }\end{array}$ & $\begin{array}{l}\text { Tidak berubah, } \\
\text { tetap tidak } \\
\text { ada }\end{array}$ \\
\hline Sewa & $\begin{array}{l}\text { Tidak berubah, tetap } \\
1 \mathrm{rt}\end{array}$ & $\begin{array}{l}\text { Meningkat } \\
\text { sebanyak 2 rt } \\
\text { (dari 2 rt menjadi 4 } \\
\text { rt) }\end{array}$ \\
\hline Milik & $\begin{array}{l}\text { Menurun sebanyak } \\
2 \mathrm{rt} \text { (dari 5 rt } \\
\text { menjadi 3 rt) }\end{array}$ & $\begin{array}{l}\text { Menurun sebanyak } \\
3 \mathrm{rt} \text { (dari } \\
8 \mathrm{rt} \text { menjadi 5 rt) }\end{array}$ \\
\hline
\end{tabular}

Data pada Tabel 1 di atas menunjukkan bahwa telah terjadi peningkatan rumah tangga yang menjadi tunakisma dan telah terjadi penurunan derajat penguasaan lahan dari pemilik menjadi penyewa, pemilik menjadi tunakisma serta bagi hasil menjadi tunakisma baik di Kampung Sampay maupun Kampung Sukatani. Oleh karena itu, penurunan derajat penguasaan lahan memiliki hubungan dengan konversi lahan dimana semakin tinggi tingkat konversi, maka semakin besar kemungkinan terjadinya penurunan derajat penguasaan lahan. Secara garis besar dapat disimpulkan bahwa konversi lahan di Desa Tugu Utara berdampak buruk pada penguasaan lahan rumah tangga setempat.

b. Perubahan Penguasaan Luas Lahan

Terjadinya perubahan derajat penguasaan lahan berhubungan dengan seberapa luas lahan pertanian yang dikuasai oleh rumah tangga dan bagaimana perubahan yang terjadi dari adanya penurunan derajat penguasaan lahan tersebut. Data pada Tabel 2 memaparkan perubahan luas lahan pertanian yang dikuasai rumah tangga Kampung Sampay dan Kampung Sukatani akibat adanya perpindahan penguasaan lahan. Perubahan luas lahan dalam penelitian ini dikategorikan menjadi lima antara lain lahan tidak ada (0 hektar), lahan sempit $(0,01$ hektar 0,24 hektar), sedang (0,25 hektar - 0,49 hektar), lahan luas $(0,50$ hektar- 0,74 hektar $)$ dan lahan sangat luas (lebih dari 0,75 hektar). 
Tabel 2. Perubahan Derajat Penguasaan Lahan Rumah Tangga Kampung Sampay dan Kampung Sukatani Periode 10 Tahun (2000-2010)

\begin{tabular}{|l|l|l|}
\hline $\begin{array}{l}\text { Derajat kuatnya } \\
\text { akses terhadap luas } \\
\text { lahan }\end{array}$ & \multicolumn{1}{|c|}{$\begin{array}{c}\text { Kampung } \\
\text { Sampay }\end{array}$} & Kampung Sukatani \\
\hline 0 hektar & $\begin{array}{l}\text { Meningkat } \\
\text { sebanyak 3 rt } \\
\text { (dari } \\
22 \text { menjadi 25) }\end{array}$ & $\begin{array}{l}\text { Meningkat } \\
\text { sebanyak 2 rt } \\
\text { (dari 15 rt } \\
\text { menjadi 17 rt) }\end{array}$ \\
\hline $\begin{array}{l}0,01 \text { hektar }-0,24 \\
\text { hektar }\end{array}$ & $\begin{array}{l}\text { Meningkat } \\
\text { sebanyak 1 rt } \\
\text { (dari } \\
1 \text { rt menjadi 2 rt) }\end{array}$ & $\begin{array}{l}\text { Menurun } \\
\text { sebanyak 1 rt } \\
\text { (dari } \\
6 \mathrm{rt} \text { menjadi 5 rt) }\end{array}$ \\
\hline $\begin{array}{l}0,25 \text { hektar - } 0,49 \\
\text { hektar }\end{array}$ & $\begin{array}{l}\text { Tidak berubah, } \\
\text { tetap 1 rt }\end{array}$ & $\begin{array}{l}\text { Meningkat } \\
\text { sebanyak 1 rt } \\
\text { (dari 1 rt menjadi } \\
2 \mathrm{rt})\end{array}$ \\
\hline $\begin{array}{l}0,50 \text { hektar }-0,74 \\
\text { hektar }\end{array}$ & $\begin{array}{l}\text { Menurun } \\
\text { sebanyak 3 rt } \\
\text { (dari 3 } \\
\text { rt menjadi tidak } \\
\text { ada) }\end{array}$ & $\begin{array}{l}\text { Meningkat } \\
\text { sebanyak 1 rt } \\
\text { (dari 1 rt menjadi } \\
2 \mathrm{rt)}\end{array}$ \\
\hline$+0,75$ hektar & $\begin{array}{l}\text { Menurun } \\
\text { sebanyak 1 rt } \\
\text { (dari 3 } \\
\text { rt menjadi 2 rt) }\end{array}$ & $\begin{array}{l}\text { Menurun } \\
\text { sebanyak 3 rt } \\
\text { (dari } \\
7 \mathrm{rt} \text { menjadi 4 rt) }\end{array}$ \\
\hline
\end{tabular}

Data pada Tabel 2 di atas menunjukkan bahwa penurunan derajat penguasaan lahan diiringi dengan penurunan derajat luas lahan yang dikuasai rumah tangga di Kampung Sampay dan Kampung Sukatani. Perubahan derajat luas lahan tersebut antara lain: 1) telah terjadi peningkatan rumah tangga yang tidak memiliki lahan dan 2) telah terjadi penurunan rumah tangga yang menguasai lahan sangat luas (lebih dari 7500 meter persegi).

\section{Persepsi Atas Kesempatan Kerja}

Ketertarikan warga ibukota untuk melakukan investasi berupa villa dan gencarnya upaya pembangunan yang dilakukan pemerintah mengakibatkan terjadinya perubahan dari berbagai aspek, termasuk kesempatan kerja. Data pada Gambar 2 menjelaskan tentang persepsi rumah tangga atas kesempatan kerja dibidang pertanian yang terjadi dalam rentang waktu sepuluh tahun (20002002) di Kampung Sampay dan Kampung Sukatani.

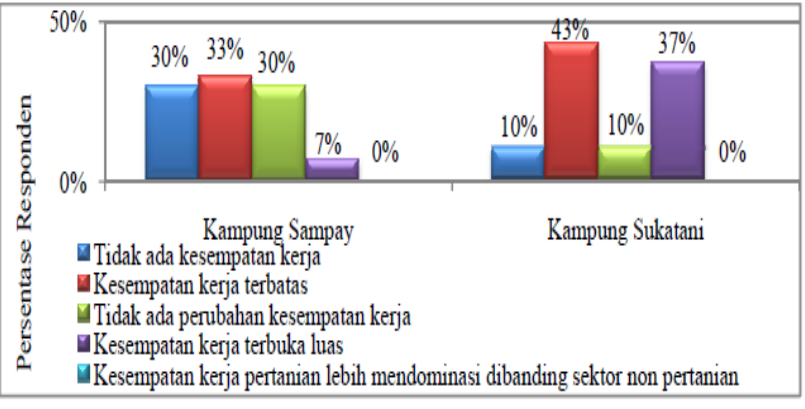

Gambar 2. Persepsi Atas Kesempatan Kerja Sektor Pertanian di Desa Tugu Utara, 2010

Data pada Gambar 2 menunjukkan bahwa terdapat perbedaan kesempatan kerja sektor pertanian antara Kampung Sukatani dan Kampung Sampay dimana kesempatan kerja di Kampung Sukatani lebih besar dibanding dengan Kampung Sampay. Hal ini dikarenakan lokasi Kampung Sukatani yang jauh dari pusat transportasi dan pemerintahan serta tingkat kecepatan terjadinya konversi cenderung lambat, sehingga masih ada lahan pertanian yang dapat dikelola rumah tangga setempat walaupun hanya sebagai buruh tani, sementara Kampung Sampay yang lokasinya dekat dengan jalan raya dan pusat pemerintahan serta tingkat kecepatan terjadinya konversi cenderung cepat, jumlah lahan pertanian sudah sangat sedikit dan sebagian besar telah beralih fungsi menjadi bangunanbangunan sehingga kesempatan kerja di sektor pertanian lebih rendah. Berdasarkan pernyataan tersebut dapat disimpulkan bahwa kesempatan kerja sektor pertanian di Desa Tugu Utara berada pada kategori terbatas, sementara itu untuk kesempatan kerja di luar sektor pertanian juga mengalami perubahan antara tahun 2000 dan tahun 2010. Data pada Gambar 3 menunjukkan tentang persepsi rumah tangga atas kesempatan kerja di luar sektor pertanian untuk dua kampung yang berbeda.

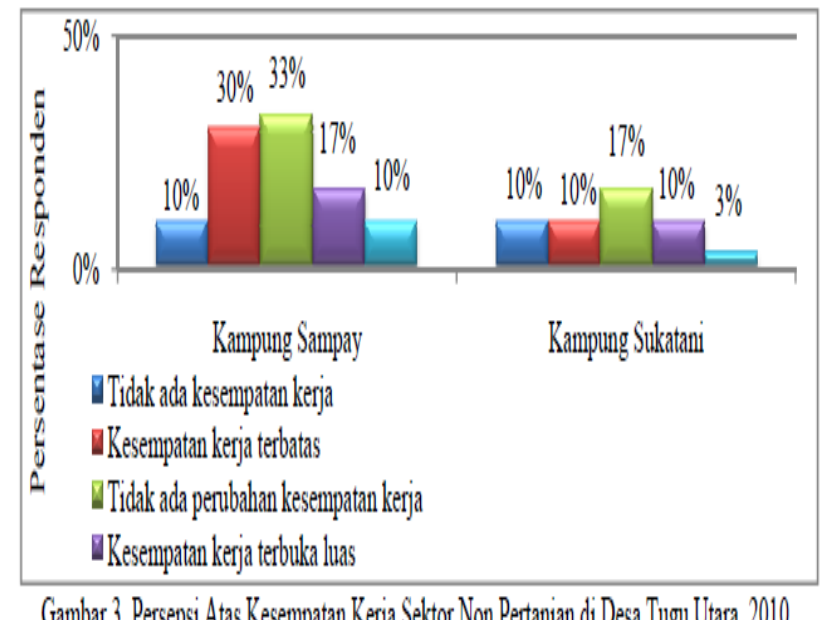

Berdasarkan data di atas terlihat bahwa kesempatan kerja non pertanian di Kampung Sampay dan Kampung Sukatani memiliki perbedaan dimana kesempatan kerja non pertanian di Kampung Sampay lebih besar dibanding Kampung Sukatani. Dari dua kampung tersebut, sebagian besar responden menyatakan bahwa kesempatan kerja disektor non pertanian saat ini lebih rendah dibanding sepuluh tahun yang lalu yaitu sebanyak 45 persen. 
Secara garis besar antara kesempatan kerja pertanian dan non pertanian baik di Kampung Sampay maupun di Kampung Sukatani adalah: 1) Kesempatan kerja pertanian di dua kampung pada tahun 2010 semakin terbatas dibanding sepuluh tahun yang lalu (tahun 2000). Akan tetapi, jika diperbandingkan antara Kampung Sampay dan Kampung Sukatani, kesempatan kerja sektor pertanian di Kampung Sukatani lebih besar dibandingkan Kampung Sampay; 2) Kesempatan kerja sektor non pertanian di Kampung Sampay lebih besar dibandingkan Kampung Sukatani, akan tetapi secara umum dari kedua kampung pada tahun 2010 kesempatan kerja mengarah pada kondisi "tetap sulit". Hal ini terjadi karena persaingan disektor non pertanian semakin lama semakin tinggi.

\section{Pola Kerja}

Pola pekerjaan berubah seiring dengan perubahan kesempatan kerja di Desa Tugu Utara. Kebanyakan rumah tangga setempat bermatapencaharian dibidang luar pertanian. Sebagian besar lahan merupakan milik warga luar desa sehingga rumah tangga setempat mengalami kesulitan untuk masuk ke bidang pertanian, kalau pun ada lahan pertanian, rumah tangga tersebut hanya berperan sebagai petani penggarap atau buruh tani. Data pada Tabel 3 menunjukkan perubahan pola kerja rumah tangga Kampung Sampay dan Kampung Sukatani dikaitkan dengan perpindahan penguasaan lahan yang mengakibatkan konversi lahan pertanian.

Tabel 3. Perubahan Pola Kerja Rumah Tangga Kampung Sampay dan Kampung Sukatani Selama 10 tahun (20002010)

\begin{tabular}{|l|l|l|}
\hline $\begin{array}{l}\text { Perubahan } \\
\text { Pola Kerja }\end{array}$ & \multicolumn{1}{|c|}{$\begin{array}{c}\text { Kampung } \\
\text { Sampay }\end{array}$} & \multicolumn{1}{|c|}{$\begin{array}{l}\text { Kampung } \\
\text { Sukatani }\end{array}$} \\
\hline Pengangguran & $\begin{array}{l}\text { Meningkat } \\
\text { sebanyak 4 rt (dari } \\
\text { tidak ada, menjadi 4 } \\
\text { rt) }\end{array}$ & $\begin{array}{l}\text { Meningkat } \\
\text { sebanyak 1 rt (dari } \\
\text { tidak ada, menjadi 1 } \\
\text { rt) }\end{array}$ \\
\hline Non Pertanian & $\begin{array}{l}\text { Meningkat 1 rt } \\
\text { (dari 22 rt } \\
\text { menjadi 23 rt) }\end{array}$ & $\begin{array}{l}\text { Menurun sebanyak 5 } \\
\text { rt (dari 11 } \\
\text { rt menjadi 7 rt) }\end{array}$ \\
\hline Petani & $\begin{array}{l}\text { Menurun sebanyak 5 } \\
\text { rt (dari 8 rt } \\
\text { menjadi 3 rt) }\end{array}$ & $\begin{array}{l}\text { Meningkat sebanyak } \\
\text { rt menjadi 8 rt) }\end{array}$ \\
\hline $\begin{array}{l}\text { Pertanian dan } \\
\text { Non }\end{array}$ & $\begin{array}{l}\text { Tidak berubah, tetap } \\
\text { tidak ada }\end{array}$ & $\begin{array}{l}\text { Tidak berubah, tetap } \\
14 \text { rt }\end{array}$ \\
\hline
\end{tabular}

Data pada Tabel 3 di atas menunjukkan bahwa terdapat perbedaan pola kerja di Kampung Sampay dan Kampung Sukatani dimana di Kampung Sampay terjadi penurunan jumlah rumah tangga yang bekerja disektor pertanian, sementara di Kampung Sukatani terjadi peningkatan jumlah rumah tangga yang bekerja disektor pertanian. Akan tetapi, secara umum rumah tangga Desa Tugu Utara bermatapencaharian di luar pertanian. Penyebab utama adalah tidak adanya lahan produktif yang dapat dikelola rumah tangga setempat, karena sebagian besar lahan produktif dikuasai oleh warga perkotaan dan sebagian lagi sudah dialihfungsikan ke bentuk diluar pertanian.

\section{Struktur Pendapatan}

Salah satu alasan terjadinya perubahan pola pekerjaan rumah tangga Desa Tugu Utara yang sebagian besar beralih ke pekerjaan sektor non pertanian adalah keinginan rumah tangga untuk memperoleh keuntungan ekonomi yang lebih dari sektor non pertanian karena adanya anggapan bahwa pendapatan dari sektor non pertanian lebih elastis ${ }^{5}$. Struktur pendapatan dalam penelitian ini dikategorikan menjadi lima yaitu: sangat rendah (Rp. 0), rendah $(<12.000 .000)$, sedang (Rp.12.000.000 $\leq \mathrm{x}<\mathrm{Rp}$. 36.000.000), tinggi (Rp. $36.000 .000 \leq x<$ Rp. 60.000.000) dan sangat tinggi $(\geq$ Rp. 60.000.000). Pengambilan data pendapatan responden dilakukan dengan merinci pendapatan per hari atau per bulan atau dalam satu tahun terakhir baik bagi rumah tangga yang bermatapencaharian disektor non pertanian atau pertanian atau juga berpola nafkah ganda. Data pada Gambar 4 di bawah ini menunjukkan pendapatan rata-rata rumah tangga selama satu tahun terakhir.

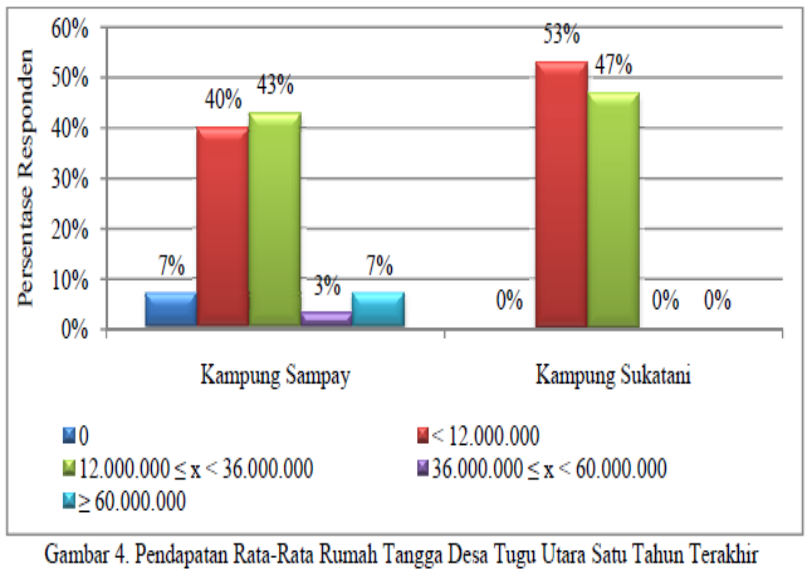

Berdasarkan data pada Gambar 4 di atas dapat ditarik kesimpulan bahwa rata-rata rumah tangga di Desa Tugu Utara memiliki pendapatan rendah yaitu kurang dari Rp. 12.000.000,00 per tahun dimana untuk rumah tangga Kampung Sampay sebanyak 40 persen dan rumah tangga Kampung Sukatani sebanyak 57 persen. Persentase tersebut menunjukkan bahwa rumah tangga Kampung Sukatani berpendapatan lebih rendah dibandingkan Kampung Sampay.

\section{Kondisi Tempat Tinggal}

Kondisi tempat tinggal dalam penelitian ini dilihat berdasarkan status penguasaan tempat tinggal, kondisi fisik tempat tinggal dan jumlah alat elektronik yang dimiliki oleh satu keluarga dalam tempat tinggalnya. Secara umum, baik Kampung Sampay maupun Kampung Sukatani memiliki tempat tinggal milik pribadi yakni sebanyak 36 rumah tangga, kemudian ada juga rumah tangga yang menumpang pada sanak saudaranya sebanyak 13 rumah tangga dengan masing-masing Kampung Sampay dan Sukatani sebanyak enam rumah tangga dan tujuh rumah tangga. Sementara itu masih ada

\footnotetext{
${ }^{5}$ Lebih elastis maksudnya lebih mudah diperoleh dan pemasukan besar
} 
juga rumah tangga yang menyewa rumah sebanyak sepuluh rumah tangga (17 persen) dengan jumlah rumah tangga Kampung Sampay sebanyak enam rumah tangga dan Sukatani sebanyak empat rumah tangga. Selain itu terdapat rumah tangga yang memiliki tempat tinggal dengan cara gadai yaitu satu rumah tangga Kampung Sampay.

Adapun untuk kondisi tempat tinggal rata-rata rumah tangga Kampung Sampay dan Kampung Sukatani berada pada kategori layak yakni dinding tembok, alas semen/keramik, dan kapasitas memadai untuk semua anggota keluarga. Selanjutnya untuk kepemilikan alat-alat elektronik, rata-rata rumah tangga di Kampung Sampay memiliki jumlah elektronik sebanyak lima sampai delapan buah, sementara rumah tangga Kampung Sukatani memiliki rata-rata memiliki jumlah alat elektronik kurang dari empat buah.

Hubungan antara status penguasaan lahan dengan kegiatan konversi lahan terlihat dari semakin tingginya jumlah tempat tinggal maka semakin besar kemungkinan terjadinya konversi lahan di desa ini. Berdasarkan data mengenai status penguasaan tempat tinggal, sebagian besar warga memiliki tempat tinggal sendiri yang dulunya merupakan lahan produktif dan kemudian dilakukan konversi menjadi tempat tinggal.

\section{Hubungan Antar Warga}

Hubungan yang terjalin antar warga baik di Kampung Sampay maupun Kampung Sukatani saat ini (2010) berbeda satu sama lain. Di Kampung Sukatani yang letaknya jauh dari jalan raya dengan tingkat konversi yang masih lebih rendah dibandingkan Kampung Sampay, hubungan yang terjalin antar warga saat ini (2010) cenderung memiliki ikatan kekerabatan yang tinggi. Hal ini disebabkan oleh intensitas warga untuk berkomunikasi satu sama lain besar, karena lokasi tempat tinggal yang berdekatan dan aktivitas warga sebagian besar dihabiskan dirumah, khususnya ibu-ibu rumah tangga. Selain itu, pola kerja warga Kampung Sukatani mangalami perubahan yang lebih baik pada sektor pertanian dimana semakin banyak rumah tangga yang bekerja sebagai petani, walaupun hanya sebagai petani penggarap. Warga yang bekerja dibidang pertanian memiliki intensitas yang tinggi untuk berkomunikasi satu sama lain, baik untuk berkebun bersama, berdiskusi bersama mengenai kondisi pertanian dan lain sebagainya, sehingga hubungan yang terjalin antar warga di kampung ini masih bersifat horizontal yaitu sesama warga.

Hubungan antar warga di Kampung Sampay yang terletak di dekat jalan raya saat ini cenderung bersifat individual. Kondisi ini terjadi akibat dari kegiatan konversi lahan. Sebelum tingkat konversi lahan semakin besar, hubungan antara warga yang satu dengan warga yang lainnya terjalin dengan baik dan ikatan kekerabatan diantara mereka juga tinggi. Warga sering berinteraksi satu sama lain. Akan tetapi, setelah terjadi konversi lahan pertanian menjadi peruntukkan lahan non pertanian, kampung ini menjadi padat oleh bangunan-bangunan berupa villa, hotel, restoran, toko dan sebagainya, sehingga mengakibatkan warga yang awalnya memiliki waktu untuk bercengkerama satu sama lain menjadi sibuk dengan pelayanannya pada para pendatang (wisatawan) dan menjadi fokus untuk memfasilitasi kegiatan para wisatawan.

Keadaan tersebut terjadi karena pola kerja yang berubah dimana warga di Kampung Sampay yang awalnya bekerja disektor pertanian beralih menjadi bekerja diluar sektor pertanian, seperti guide, sopir taksi, penjaga villa, penjaga toko, dan sebagainya. Akibatnya, terjalin hubungan yang bersifat vertikal yaitu antara warga lokal dengan wisatawan baik pemilik villa, hotel, restoran, maupun toko dan kondisi ini menyebabkan sebagian besar warga mengalami ketergantungan sosial pada para wisatawan.

\section{7. a. Prostitusi}

Perubahan peruntukkan lahan pertanian menjadi peruntukkan lahan non pertanian di Desa Tugu Utara yang sebagian besar dialihkan menjadi villa, hotel, dan restoran mendukung kegiatan pariwisata di kawasan Puncak, sehingga menarik para wisatawan untuk menghabiskan liburannya di kawasan ini. Akan tetapi, kondisi ini dijadikan kesempatan oleh pihak-pihak yang tidak bertanggung jawab untuk melakukan kegiatankegiatan asusila.

Kawasan Puncak selain terkenal dengan pemandangannya yang elok, juga terkenal dengan adanya kegiatan prostitusi khususnya kegiatan kawin kontrak yang dilakukan secara ilegal. Desa Tugu Utara menjadi sorotan publik untuk masalah ini karena di desa ini terdapat "Kampung Arab" yang penuh dengan orangorang Arab. Biasanya orang Arab yang mengunjungi wilayah ini datang secara berkala, sehingga akrab dengan warga setempat seperti tukang salon dan pedagang-pedagang lainnya. Awalnya oknum-oknum yang menjadi pelaku kawin kontrak ini adalah seorang PSK (Pekerja Seks Komersial) yang berasal dari Cianjur, Sukabumi, dan Indramayu. Ketika dilakukan "penggrebekan" oleh aparat setempat, KTP (Kartu Tanda Penduduk) pelaku bukan berasal dari warga lokal dan tidak ada warga lokal yang mengenal para pelaku "biasanya PSK berasal dari luar desa, gak mungkin lah kalau warga asli sini, karena malu kalau ketahuan" (Bapak Ddi, 50 tahun). Akan tetapi semakin lama kegiatan prostitusi menimbulkan pengaruh kepada warga lokal yang tidak memiliki nilai-nilai moral dan sosial untuk mengikuti jejak sebagai PSK. Kondisi lingkungan yangcenderung individualistik atau acuh tak acuh mengakibatkan warga khususnya anak-anak muda mudah mendapatkan pengaruh dari para pengunjung mulai dari gaya hidup sampai pada kegiatan asusila. Warga lokal yang memiliki kadar keimanan yang rendah dan terdesak oleh perekonomian yang rendah menjadi terpengaruh untuk melakukan kegiatan prostitusi karena menghasilkan uang yang banyak.

Prosedur kawin kontrak ini tidak sesuai dengan akidah islam, para oknum tersebut menggunakan 
"wali gadungan". Hal ini dilakukan asalkan menurut para pelaku sudah sah sebagai suami istri. Biasanya kawin kontrak ini terjadi pada bulan Juni dan dilakukan hanya beberapa bulan saja selama orang Arab itu berada di Indonesia. Setelah orang-orang Arab akan kembali ketanah airnya, kawin kontrak pun berakhir dan terjadilah perceraian. Pihak-pihak yang terlibat kawin kontrak memperoleh sejumlah uang sebagai upah. Selain orang-orang Arab tersebut, banyak pengunjung yang juga melakukan kegiatan yang melanggar aturan agama dan nilai-nilai sosial seperti ini. Akan tetapi kegiatan ini cenderung terjadi secara aman dan terselubung karena dilakukan di dalam villa bahkan mobil yang secara tidak langsung tidak mungkin dapat dijangkau oleh aparat.

\section{Dampak Sosio-Ekologis Konversi Lahan}

Konversi lahan pertanian di Desa Tugu Utara terjadi sebagai konsekuensi logis dari perkembangan pembangunan yang mengarah pada berkurangnya lahanlahan produktif, khususnya lahan pertanian. Lahan pertanian sebenarnya memberikan manfaat bagi lingkungan disekitarnya karena menjaga keutuhan lahan. Akan tetapi fenomena konversi lahan yang semakin lama semakin meningkat dan sulit untuk diatasi menyebabkan timbulnya berbagai dampak bagi sosial ekologi Desa Tugu Utara. Adapun dampak sosial ekologi konversi lahan tersebut antara lain dampak pada akses rumah tangga terhadap air, cara warga membuang limbah rumah tangga, dan yang paling utama adalah terjadinya degradasi lingkungan seperti banjir, longsor dan kebisingan. Terdapat keterkaitan antara dampak sosioekologis konversi lahan dengan tipe konversi lahan yang terjadi di Desa Tugu Utara dimana antara Kampung Sampay dan Kampung Sukatani mengalami perbedaan dalam memperoleh dampak tersebut.

\section{Akses Rumah Tangga Terhadap Sumberdaya Air}

Akses rumah tangga terhadap sumberdaya air dapat dikatakan mudah dan terjangkau untuk semua kalangan karena sebagian besar warga memanfaatkan mata air Sungai Ciliwung sebagai sarana untuk memenuhi kebutuhan air. Berikut ini adalah data mengenai akses warga terhadap sumberdaya air yang divisualisasikan pada Gambar 5.

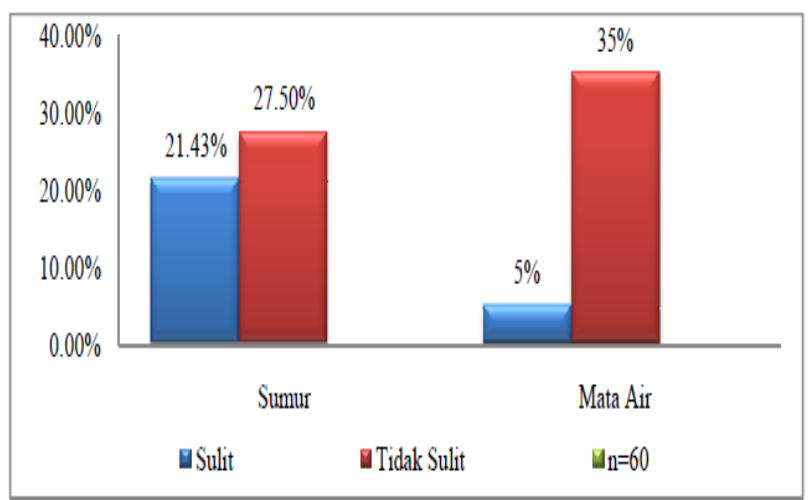

Gambar 5. Akses Sumberdaya Air Rumah Tangga Desa Tugu Utara, 2010
Berdasarkan data pada Gambar 5 di atas dapat dilihat bahwa sebagian besar rumah tangga memperoleh air dari mata air Sungai Ciliwung sebanyak 40,00 persen dengan rincian rumah tangga yang kesulitan memperoleh air sebanyak lima persen dan yang tidak kesulitan memperoleh air sebanyak 35,00 persen ${ }^{6}$. Sementara itu rumah tangga yang menggunakan sumur di Desa Tugu Utara sebanyak 48,93 persen dengan rincian rumah tangga yang mengalami kesulitan air sebanyak 21,43 persen dan yang mudah memperoleh air sebanyak 27,50 persen.

Air yang dimanfaatkan oleh rumah tangga Desa Tugu Utara sejauh ini memiliki kualitas yang baik karena sebagian besar rumah tangga memperoleh air langsung dari mata air Sungai Ciliwung. Kualitas yang baik ini merujuk pada kondisi air yang tidak berasa, tidak berbau dan tidak berwarna. Berikut ini adalah data mengenai kualitas air di Desa Tugu Utara yang diperoleh dari 60 responden baik rumah tangga Kampung Sampay maupun rumah tangga Kampung Sukatani.

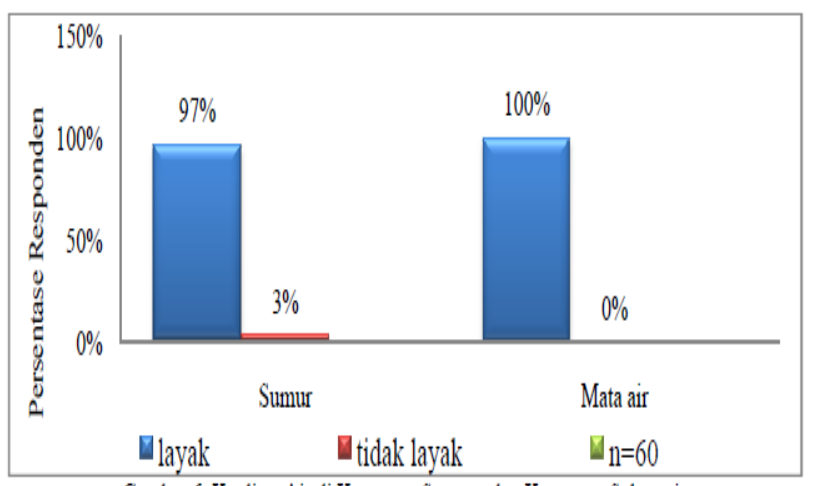

Gambar 6. Kualitas Air di Kampung Sampay dan Kampung Sukatani

Data pada Gambar 6 menunjukkan bahwa secara umum air yang dimanfaatkan oleh rumah tangga untuk kebutuhan sehari-hari berada pada kondisi yang layak untuk dikonsumsi. Walaupun terdapat satu rumah tangga yang menyatakan bahwa air yang dimanfaatkan olehnya yaitu air yang berasal dari sumur berada pada kondisi tidak layak. Namun keadaan tidak layak ini terjadi hanya pada waktu-waktu tertentu saja, misal pada musim kemarau sehingga air terkadang menjadi kotor. Akan tetapi, walaupun sebagian besar air yang ada di desa ini berada pada kondisi layak konsumsi, rumah tangga di kampung yang dekat dengan jalan raya yaitu Kampung Sampay biasanya membeli air minum di tempat isi ulang, karena ada sebagian rumah tangga yang malas untuk memasak air. Hal ini dikemukakan oleh Bapak Rzl (29 tahun).

Berdasarkan fakta di atas dapat disimpulkan bahwa dampak konversi lahan terhadap ketersediaan sumberdaya

\footnotetext{
${ }^{6}$ Kesulitan memperoleh air artinya pada musim kemarau warga sulit memperoleh air karena terjadi kekeringan. Fenomena ini terjadi karena kawasan Puncak mengalami degaradasi lingkungan yang mengakibatkan resapan air terganggu akibat konversi lahan. Sementara untuk warga yang tidak kesulitan memperoleh air tidak mengalami kekeringan baik pada musim kemarau atau pun musim lainnya
} 
air masih tergolong melimpah. Konversi lahan pertanian di Desa Tugu Utara, khususnya di kawasan yang dekat dengan jalan raya menyebabkan tersedianya sarana dan prasarana perekonomian. Hal ini berimplikasi pada kebiasaan hidup rumah tangga setempat. Rumah tangga Kampung Sampay yang berada dekat jalan raya dan pusat perekonomian desa lebih memilih untuk membeli air minum dari depot isi ulang yaitu sebanyak sepuluh persen, karena selain harganya yang murah dan terjangkau untuk semua kalangan tetapi juga karena adanya kemalasan rumah tangga untuk memasak air. Sementara bagi rumah tangga Kampung Sukatani memasak air sendiri lebih baik dibandingkan harus pergi terlebih dahulu ke tempat depot isi ulang yang jaraknya jauh.

\section{Cara Warga Membuang Limbah Rumah Tangga}

Konversi lahan pertanian menjadi peruntukkan lahan non pertanian antara Kampung Sampay dan Kampung Sukatani mengalami perbedaan. Konversi lahan di Kampung Sampay berlangsung secara besar-besaran karena lokasinya yang dekat dengan jalan raya, sehingga terjadi peningkatan jumlah bangunan seperti villa, hotel, restoran dan toko. Seperti pada uraian sebelumnya mengenai perubahan pola kerja, warga Kampung Sampay rata-rata bermatapencaharian dibidang non pertanian. Berbeda halnya dengan kondisi di Kampung Sukatani dimana konversi lahan pertanian masih tergolong rendah, sehingga di kampung ini masih kaya akan lahan pertanian, sehingga warga setempat rata-rata bermatapencaharian dibidang pertanian. Perbedaan ini berpengaruh terhadap sikap warga terhadap lingkungan, salah satunya adalah kebiasaan warga setempat dalam mengelola limbah rumah tangga.

Rumah tangga Kampung Sampay dan Kampung Sukatani memiliki cara sendiri dalam mengelola limbah rumah tangga, ada yang menjadikan sampah sebagai pupuk kompos, membakarnya, namun ada juga rumah tangga yang membuang sampah ke sungai dan lahan kosong milik orang lain. Di desa ini tidak tersedia fasilitas pembuangan sampah yang memadai, sehingga keterbatasan dalam hal penyediaan tempat pembuangan sampah menyebabkan rumah tangga membuang sampah sembarangan. Berikut ini adalah data mengenai cara rumah tangga desa membuang sampah limbah rumah tangga yang dipaparkan pada Gambar 7 .

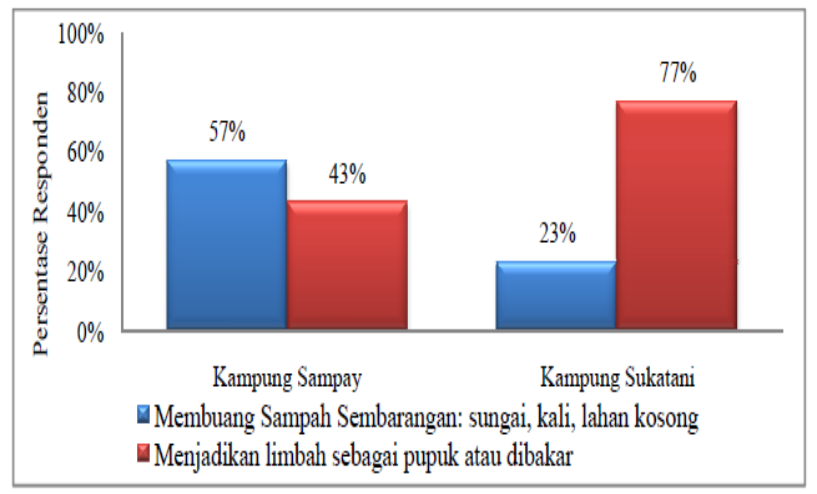

Gambar 7. Cara rumah tangga Desa Tugu Utara Membuang Limbah Rumah Tangga

Data pada Gambar 7 menunjukkan perbedaan antara rumah tangga Kampung Sampay dan rumah tangga
Kampung Sukatani dalam mengelola limbah rumah tangga. Sebagian besar rumah tangga Kampung Sampay membuang sampah sembarangan dan rata-rata membuangnya ke kali atau sungai sebanyak 57 persen. Rumah tangga tersebut membuang sampah sembarangan karena tidak tersedianya tempat pembuangan sampah yang layak untuk menampung limbah rumah tangga yang dihasilkan oleh rumah tangga setempat, selain itu hanya sedikit rumah tangga yang bergerak dibidang pertanian sehingga hanya 43 persen rumah tangga yang mengelola sampah menjadi pupuk ataupun membakarnya. Kebiasaan rumah tangga membuang sampah ke sungai berpengaruh pada kondisi air sungai yang menjadi kotor. Pihak yang membuang sampah ke sungai, selain warga lokal juga warga luar desa yang berkunjung ke kawasan Puncak, sehingga keduanya berperan dalam tercemarnya air sungai, hal ini dinyatakan oleh Bapak Ymc (42 tahun).

Berbeda dengan kondisi di Kampung Sukatani dimana rata-rata rumah tangga setempat menjadikan sampah sebagai pupuk organik (kompos) sebanyak 77 persen, karena sebagian besar rumah tangga bekerja disektor pertanian sehinggadengan memanfaatkan limbah rumah tangga dapat memberikan keuntungan di bidang pertanian. Selain dijadikan pupuk, sebagian rumah tangga lainnya memilih untuk membakar limbah-limbah yang dihasilkan dari rumah tangganya agar lingkungan terlindungi. Walaupun begitu rumah tangga Kampung Sukatani juga ada yang membuang limbah rumah tangga ke sungai sebanyak 23 persen.

Berdasarkan uraian di atas dapat disimpulkan bahwa konversi lahan memberikan dampak tidak langsung pada kebiasaan rumah tangga Desa Tugu Utara dalam mengelola limbah rumah tangga. Kampung yang dekat dengan jalan raya dan rata-rata bermata pencaharian dibidang non pertanian yaitu Kampung Sampay cenderung membuang limbah rumah tangga ke sungai, sementara Kampung Sukatani yang lokasinya jauh dari jalan raya dan mata pencaharian rumah tangga rata-rata dibidang pertanian cenderung memanfaatkan limbah rumah tangga sebagai pupuk atau membakarnya.

\section{Degradasi Lingkungan}

Perubahan peruntukkan lahan pertanian menjadi peruntukkan lahan non pertanian di Desa Tugu Utara menyebabkan kawasan ini menjadi padat dengan pemukiman-pemukiman, sehingga terjadi penurunan daya dukung lingkungan yang pada akhirnya menyebabkan banjir dan longsor. Desa Tugu Utara merupakan desa yang berada di bagian hulu DAS Ciliwung, walaupun berada di bagian paling hulu, tidak menutup kemungkinan kawasan ini mengalami bencana alam seperti banjir dan longsor akibat konversi lahan.

\section{a. Banjir dan Longsor}

Alih fungsi lahan pertanian menjadi peruntukkan lahan non pertanian antara tahun 2000 sampai 2010 mengalami perbedaan dimana kondisi saat ini (2010) bangunan-bangunan semakin bertambah, sementara tahun 2000 pembangunan tidak sebesar sekarang. Kondisi ini mengakibatkan lahan untuk resapan air semakin berkurang, apalagi jika pembangunan yang 
dilakukan tidak sesuai dengan aturan yang telah ditetapkan. Seperti pada bahasan sebelumnya, banyak bangunan-bangunan yang menyalahi aturan misalnya dengan membuat bangunan di pinggir kali yang mengakibatkan menyempitnya lebar kali sehingga terjadi luapan air yang melebar ke jalan-jalan apalagi saat hujan sehingga berpotensi banjir. Berdasarkan hasil wawancara melalui kuesioner dengan rumah tangga setempat, rumah tangga yang menyatakan pernah ada kejadian banjir di dekat rumahnya berjumlah delapan rumah tangga pada tahun 2010, sementara tahun 2000 tidak ada rumah tangga yang menyatakan pernah terjadi banjir.

Kejadian banjir tersebut terjadi di kawasan hulu DAS Ciliwung yang berada di atas ketinggian. Jika terjadi banjir di kawasan ini maka kawasan yang berada di bagian hilir DAS Ciliwung mengalami ancaman yang lebih besar terkena banjir, karena adanya interkoneksitas antara bagian hulu dan hilir DAS Ciliwung. Oleh karena itu, tata ruang yang ada di hulu perlu mendapat perhatian yang besar karena dapat menimbulkan dampak negatif terhadap lingkungan tidak hanya di kawasan terjadinya konversi tetapi juga kawasan yang ada di bagian hilir.

Alih fungsi lahan pertanian menjadi peruntukkan lahan non pertanian selain menimbulkan bencana banjir juga dapat menyebabkan terjadinya longsor. Kondisi yang berbeda juga terjadi antara tahun 2000 sampai 2010 dimana bencana longsor di tahun 2010 lebih sering terjadi dibandingkan tahun 2000. Terdapat 18 rumah tangga yang menyatakan pernah terjadi longsor di dekat rumahnya pada tahun 2010. Salah satu kasus longsor di Desa Tugu Utara terjadi pada keluarga Bapak Asp (40 tahun).

Penyebab paling utama dari adanya bencana banjir dan longsor ini adalah masalah tata ruang. Masalah tata ruang menjadi suatu permasalahan ketika konversi lahan pertanian atau lahan produktif ke pemanfaatan diluar pertanian tidak sesuai dengan peraturan-peraturan yang telah ditetapkan. Misalnya ada got yang lebarnya sebesar satu meter, kemudian dibangun villa di depan got tersebut dan mengakibatkan lebar got terambil menjadi setengah meter, sehingga kapasitas air untuk satu meter berubah menjadi setengah meter. Kemudian ketika ada hujan besar, air dalam got ikut membesar sehingga got yang sudah menyempit tidak mampu lagi menampung kapasitas air yang terus meningkat,maka terjadilah luapan air yang berakhir dengan bencana banjir. Intinya berbagai bencana baik banjir maupun longsor terjadi karena masalah resapan air yang terganggu oleh kegiatan konversi lahan di lahan hijau.

\section{b. Kebisingan dan Kemacetan}

Konversi lahan pertanian telah memberikan perubahan ada kondisi lingkungan Desa Tugu Utara. Banyaknya bangunan-bangunan seperti villa dan tersedianya sarana prasarana transportasi menyebabkan kawasan ini ramai didatangi pengunjung. Banyaknya pengunjung yang memadati kawasan Puncak dan melewati wilayah Desa Tugu Utara menyebabkan timbulnya polusi suara yang dihasilkan dari kendaraan bermotor atau pun dari hiruk pikuk para pengunjung yang beristirahat di villa. Polusi suara ini berupa kebisingan yang menimbulkan gangguan komunikasi bagi warga yang dekat jalan raya dan terganggunya ketenangan bagi warga yang tempat tinggalnya dekat dengan vilavila, karena para pengunjung membuat acaraacara yang menimbulkan kegaduhan. Berikut ini adalah data mengenai rumah tangga yang merasa terganggu oleh kebisingan yang ditimbulkan oleh para pengunjung.

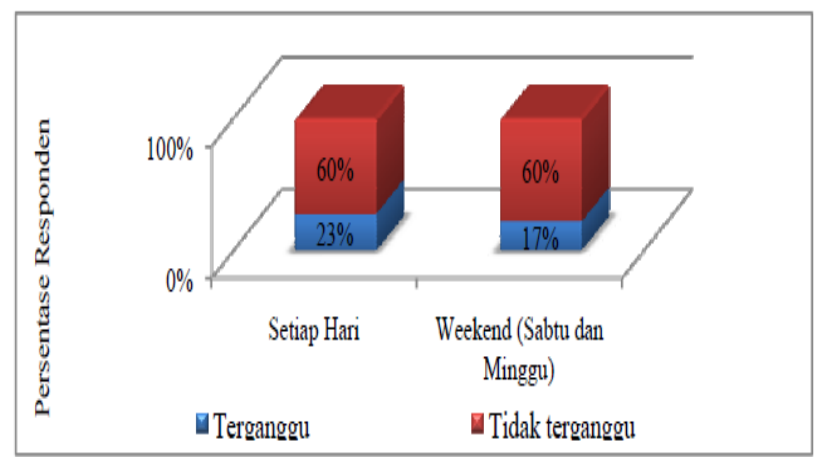

Gambar 8. Penganuh dan Waktu Kejadian Terjadinya Gangguan Kebisingan

Data pada Gambar 8 menunjukkan bahwa rumah tangga yang merasa terganggu oleh kebisingan yang ditimbulkan baik dari alat transportasi maupun dari hiruk pikuk para pendatang jumlahnya lebih sedikit dibandingkan dengan rumah tangga yang merasa tidak terganggu, yaitu sebanyak 40 persen dengan rincian setiap hari sebanyak 23 persen dan weekend sebanyak 17 persen.

Rumah tangga yang merasa tidak terganggu oleh kebisingan tersebut menyatakan sudah terbiasa dengan keadaan lingkungan yang seperti itu, sehingga adanya polusi suara bukan lagi masalah bagi rumah tangga setempat, selain kebisingan, kawasan Puncak juga terkenal dengan rawan kemacetan. Kemacetan yang terjadi menimbulkan keuntungan sekaligus kerugian bagi warga setempat dan pengguna jalan yang sebagian besar membawa kendaraan berplat nomor B yaitu Jakarta. Keuntungan yang diperoleh bagi warga setempat berupa larisnya dagangan yang dijual, sedangkan bagi para pengguna jalan yang bertujuan untuk bersantai dapat menghadapi kemacetan sambil menikmati keindahan panorama alam Puncak. Namun kerugian yang diperoleh baik oleh warga setempat maupun pengguna jalan adalah polusi 
suara dan polusi udara, serta bagi pengguna jalan lainnya yaitu terbuangnya waktu yang sia-sia.

\section{KESIMPULAN}

Konversi lahan pertanian adalah perubahan peruntukkan lahan pertanian menjadi peruntukkan lahan non pertanian. Lahan potensial yang banyak terkonversi di Desa Tugu Utara selama sepuluh tahun terakhir (2000-2010) adalah lahan sawah dan lahan kering yang mengalami perubahan peruntukkan lahan menjadi rumah, villa, hotel, restoran, toko, dan sebagainya. Terdapat perbedaan tipe konversi lahan antara Kampung Sampay yang lokasinya dekat dengan jalan raya dan Kampung Sukatani yang lokasinya jauh dari jalan raya. Kampung Sampay mengalami konversi lahan pertanian Tipe I, sementara Kampung Sukatani mengalami konversi lahan pertanian Tipe II. Secara umum, konversi lahan pertanian di Desa Tugu Utara baik di Kampung Sampay maupun Kampung Sukatani memberikan dampak negatif pada aspek sosioekonomis seperti perubahan penguasaan lahan, kesempatan kerja, perubahan pola kerja, kondisi tempat tinggal, dan hubungan antar warga (konflik dan prostitusi), serta memberikan dampak negatif pada aspek sosio-ekologis seperti akses terhadap sumberdaya air, cara warga membuang limbah rumah tangga yang merupakan dampak tidak langsung akibat konversi lahan pertanian, dan terjadinya degradasi lingkungan seperti banjir, longsor dan kebisingan.

\section{DAFTAR PUSTAKA}

Adiwibowo,S. 2007. Paradigma, Perspektif dan Etika Ekologi. Dalam

Adiwibowo (ed). 2007. Ekologi Manusia. Bogor: Fakultas Ekologi Manusia.

Akib, N.N. 2002. Studi Keterkaitan Antara Nilai Manfaat Lahan (Land Rent) dan Konversi Lahan Pertanian di Kecamatan Pancoran Mas Kota Depok. Tesis. Tidak dipublikasikan.

Dharmawan, A.H. 2007. Antropologi Budaya, Sosiologi Lingkungan dan Ekologi Politik. dalam Adiwibowo (ed). 2007. Ekologi Manusia. Bogor: Fakultas Ekologi Manusia.

Sihaloho, M. 2004. Konversi Lahan Pertanian dan Perubahan Struktur Agraria: Kasus Mulyaharja, Kecamatan Bogor Selatan, Kota Bogor, Jawa Barat. Tesis. Tidak dipubllikasikan.

Singarimbun, Masri. 1989. Metode Penelitian Survei. Jakarta: LP3ES

Utama, D.F. 2006. "Analisis Faktor-Faktor yang Mempengaruhi Konversi Lahan Sawah ke Penggunaan Non Sawah di Kabupaten Cirebon". Skripsi. Tidak dipublikasikan.

Iqbal, M dan Soemaryanto. 2007. Strategi Pengendalian Alih Fungsi Lahan Pertanian Bertumpu Pada Partisipasi Masyarakat. http://pse.litbang.deptan.go.id/ind/pdffiles/ART52c.pdf. diakses tanggal 29 Maret 20.15 WIB.
Soemaryanto, dkk. 2001. Konversi Lahan Sawah ke Penggunaan Non Pertanian dan Dampak Negatifnya.

http://pse.litbang.deptan.go.id/ind/pdffiles/ART52c.pdf. diakses tanggal 29 Maret 2010, pukul 20.24 WIB. 